\title{
Identification and Characterization of Molecules Having Anti-microbial Activities from Rabbit Epididymis Using Proteomic Approach
}

\author{
Reddy K.V.R*, Sukanya Deva, Clara Aranha, Mandar S. Patgaonkar and Gauri Bhonde
}

Division of Molecular Immunology, National Institute for Research in Reproductive Health (NIRRH), Indian Council of Medical Research (ICMR), Jehangir Merwanji Street, Parel, Mumbai - 400 012, India

\begin{abstract}
Antimicrobial peptides (AMPs) are the key components of the host innate immune system and form the first line of host defense against invading pathogens. In the present study attempts were made to identify and characterize AMPs that are synthesized in the epididymal epithelial cells (EPECs) of rabbit, Oryctologus cuniculus. Ex-vivo induction of EPECs with TLR-9 ligand, CpG-ODN-2006 resulted an up-regulation of several AMPs. These molecules were identified in the acid extracts of pooled epididymal tissue homogenates using proteomic approach (Ultrafiltration, cation-exchange chromatography, RP-HPLC, Far Western blotting - FWB, 2D-PAGE and MALDI-TOF-MS). The pooled RP-HPLC fraction (peaks 1-5), named as rabbit epididymal secretory antimicrobial protein (RESAMP), showed activity against several pathogens. FWB, 2D-PAGE and MALDI-TOF-MS results revealed that of the $\sim 19$ proteins identified, four protein sequences (hemoglobin- $\alpha / \beta$ subunits, transthyretin and calreticulin) found to be reacted with HIV antigens (gp120, gp17, gp41, p24). One of the four sequences (VLSHHFGKEFTPQVQ) showed $>90 \%$ homology with hemohlobin- $\beta$ protein. A 29 mer peptide with VLSHHFGKEFTPQVQ sequence designated as rabbit epididymal hemoglobin beta $(\mathrm{REHb} \beta \mathrm{P})$. The synthesized peptide showed the highest Probability Based Mowse Score (PBMS) and demonstrated good bactericidal activity (Escherichia coli, Pseudomonas aeruginosa, Staphylococcus aureus, Streptococcus pyogenes and Candida albicans. REHb $\beta P$ did not show cytotoxicity against human endocervical cells (End1/E6E7) and rabbit erythrocytes. Immunofluorescent results revealed that REHbßP localized in the stereocilia epididymis and on the acrosome of ejaculated spermatozoa of rabbit. To the best our knowledge, this is the first study describing the detection of AMPs in rabbit epididymis. In conclusion, the present study suggests that EPECs derived REHb $\beta P$ may have therapeutic potential in the management of reproductive well being of human and animals.
\end{abstract}

Keywords: Rabbit; Epididymal epithelial cells (EPECs); REHb $\beta$; AMPs

\section{Introduction}

Peptides with antimicrobial activities have been discovered across virtually all forms of life as a primitive component of their innate immune system and are constitutively or inducibly expressed in response to invasion by pathogens [1,2]. A number of microorganisms infect reproductive tract in humans and animals, with serious consequences for reproductive function [3]. In men, the penile urethra is the portal of entry for pathogens (eg: Neisseria gonorrhoeae and Chlamydia trachomatis) and urethritis is the most common clinical syndrome [4]. Occasionally, these pathogens can also ascend into deeper organs such as the epididymis [4]. Retrograde infection of the epididymis may also occur from microorganisms present in the vas deferens, or via the blood vessels supplying epididymis. A common result of microbial infection of the epididymis is epididymitis [5], the condition that may lead to the destruction of the epididymal duct and transient or permanent sterility in mammals [3].

Epididymal epithelial cells (EPECs) form a barrier to create an unique microenvironment in the lumen, where interactions between EPECs and spermatozoa take place via the fluid milieu [6]. Spermatozoa bind a variety of proteins as they pass through the epididymis [7]. Besides sperm maturation and fertilization, epididymis is known to have efficient self-defense mechanisms against bacterial infection $[2,8]$. Recent studies have shown that EPECs of rat, mice and human synthesize molecules having antimicrobial activities. Some of them are Bin- $1 \beta$ [9], Eppin [8] , SPAG-11 [2], HE2- $\alpha$ [10], $\beta$-defensins [2,11], SOB3 [12], EP2/HE2 [4], hCAP-18 [13], and cystatin-11 [14] etc. Despite the progress made in other species, the repertoire of host defense molecules also known as antimicrobial peptides (AMPs) having microbicidal activities have not been investigated previously in the epididymis of rabbit, Oryctologus cuniculus. To the best of our knowledge this is the first study dealing the identification and characterization of AMPs in the rabbit epididymis.

Rabbits are being used widely as a first choice in vivo model to evaluate the safety of various products before planning for expensive clinical trials [1]. Since the emergence of antibiotic-resistant pathogenic bacteria, the discovery of new AMPs to substitute for traditional antibiotics has become increasingly important [15]. Therefore, in the present study we intended to identify, isolate and characterize AMPs that are synthesized along the epididymis and secreted into the lumen.

The results of the present study demonstrated that using proteomic approach, we generated rabbit epididymal AMP repertoire and compared with the AMP repopertoire obtained after Ex-vivo induction of rabbit epididymis by CpG-ODN-2006, a ligand for tolllike receptor-9 (TLR-9). The ligand induced the synthesis of new

*Corresponding author: Dr KVR Reddy, Division of Molecular Immunology, National Institute for Research in Reproductive Health (NIRRH), Indian Council of Medical Research (ICMR), Jehangir Merwanji Street, Parel, Mumbai - 400012 , India, Tel: +91-22-24192016, Fax: +91-22-24139412; E-mail: reddyk@nirrh.Res.in

Received August 03, 2011; Accepted November 08, 2011; Published November 21, 2011

Citation: Reddy KVR, Deva S, Aranha C, Patgaonkar MS, Bhonde G (2011) Identification and Characterization of Molecules Having Anti-microbial Activities from Rabbit Epididymis Using Proteomic Approach. J Microbial Biochem Technol S2:002. doi:10.4172/1948-5948.S2-002

Copyright: (c) 2011 Reddy KVR, et al. This is an open-access article distributed under the terms of the Creative Commons Attribution License, which permits unrestricted use, distribution, and reproduction in any medium, provided the original author and source are credited 
Citation: Reddy KVR, Deva S, Aranha C, Patgaonkar MS, Bhonde G (2011) Identification and Characterization of Molecules Having Anti-microbial Activities from Rabbit Epididymis Using Proteomic Approach. J Microbial Biochem Technol S2:002. doi:10.4172/1948-5948.S2-002

Page 2 of 11

and constitutively expressed AMPs. One of the molecule having antimicrobial activity was identified and named as rabbit epididymal hemoglobin beta peptide (REHbßP). The peptide did not lyse RBCs or decrease the viability of human vaginal cells. Immunofluorescence studies reveal that REHb $\beta \mathrm{P}$ found to be localized in epididymis and spermatozoa. The study would aid in designing newer intervention strategies for the prevention of sexually transmitted infections (STI's).

\section{Materials and Methods}

\section{Animals}

Healthy and sexually mature male Belgium white rabbits (mean age $10 \pm 1 \mathrm{month}$; mean body weight, $3 \pm 0.50 \mathrm{~kg}$ ) were maintained under standard laboratory conditions (temperature $20 \pm 1^{\circ} \mathrm{C}$, relative humidity $50 \pm 10 \%$, and $12 \mathrm{~h}$ light: $12 \mathrm{~h}$ darkness cycle). Animals were housed individually in stainless steel cages, food and water were made available ad libitum.

Adult female Holtzman rats weighing 120 gm were used for raising anti-peptide antibodies. The study was approved by the Animal Ethics Committee of the National Institute for research in Reproductive Health (NIRRH), Parel, Mumbai (IAEC \# 05/08) and the Committee for the Purpose of Control and Supervision of Experiments on Animals (CPCSEA), Ministry of Social Justice and Empowerment, Government of India.

\section{Reagents}

The peptides viz., REHb $\beta$ P, hemoglobin- $\alpha$, transthyretin and calreticulin were commercially procured (USV Ltd., Mumbai, India). Goat anti-rat and goat anti-human secondary antibodies, cell culture reagents and media used in various experiments were procured from Sigma, USA. CpG-ODN-2006 was obtained from In Vitrogen Life science technology, USA For the preparation of stock solutions, all the reagents were dissolved in endotoxin-free water (Sigma). Unless otherwise stated, all other chemicals and buffers are of high grade quality were procured from local suppliers.

\section{Bacterial strains and culture}

The clinical isolates were obtained from patients attending the microbiology laboratory, King Edward Memorial Hospital, Mumbai, India. Vaginal swabs were taken and cultured in respective growth media. Identification of the organisms was done by biochemical tests, and their antibiotic sensitivity was determined by standard criteria [16]. For antibacterial testing clinical pathogens viz., C.albicans and Gram negative bacteria (Escherichia coli, and Pseudomonas aeruginosa), and Gram positive bacteria (Staphylococcus aureus and Streptococcus pyogenes) were used. The bacteria were grown at $37^{\circ} \mathrm{C}$ overnight in Muller Hinton Broth (MHB) or Sabouraud dextrose agar (for C.albicans) (Hi-Media laboratories Pvt Ltd, Mumbai, India) and then subcultured into fresh broth and raised to log phase for 4-6 h. The cultures were centrifuged at $6000 \mathrm{rpm}\left(10 \mathrm{~min}, 4^{\circ} \mathrm{C}\right)$ and the pellets washed twice in sterile $10 \mathrm{mM}$ sodium phosphate buffer $(\mathrm{pH}$ 7.4) and resuspended in the same buffer. All bacterial suspensions were calibrated and routinely standardized to an absorbance of 0.5 at 630 $\mathrm{nm}$, which gave a concentration of approximately $10^{8}$ Colony Forming Units (CFU) /ml)

\section{Ex-vivo induction and extraction of AMPs from rabbit epididymis}

Epididymis was removed from the rabbits $(\mathrm{N}=22)$ at various time points during the course of the present study (June-2007 to May
2010). The tissues were cleaned from superficial fluid, fat body and blood stain by gently blotting onto Kleenex paper and immersed in $10 \mathrm{ml}$ PBS. A single dose $(10 \mu \mathrm{g} / \mathrm{gm}$ tissue $)$ of 25 mer peptide, CpGODN-2006 (5'-tcgtcgtcgttcgaacgacgttgat-3'), a pathogen associated molecular pattern (PAMP) was administered Ex-vivo into the caput and cauda regions of intact epididymis and incubated for $6 \mathrm{~h}$ at $37^{\circ} \mathrm{C}$ in $\mathrm{CO}_{2}$ incubator in the presence 199 medium. Following washing in the same medium, epididymal tissue was minced with fine scissor and homogenized in PBS (pH:7.4). During collection and processing of the tissue, utmost care was taken to avoid sample contamination with blood. The homogenate was centrifuged at 10, $000 \mathrm{~g}$ for $15 \mathrm{~min}$ at $4^{\circ} \mathrm{C}$. The resulting supernatant was collected, dialyzed using Amicon ultrafiltration unit with a $30 \mathrm{kDa}$ cut-off membrane (Millipore, MA USA). The unit was centrifuged at $5000 \mathrm{~g}$ for $30 \mathrm{~min}$ and the filtrate was lyophilized. The lyophilized samples were dissolved in required amount of endotoxin free water (Sigma) and determined the total protein concentration [17] before subjected to purification by cationexchange chromatography.

\section{Cation-exchange chromatography}

Cation-exchange chromatography was performed as described by Yedery and Reddy [18] with following modifications. The dialyzed extract of epididymal tissue extract $(5 \mathrm{ml})$ was loaded onto a $24 \mathrm{X} 1.8$ cm glass column packed with carboxy methyl cellulose-CMC (Sigma, USA), equilibrated with $0.2 \mathrm{M}$ sodium acetate ( $\mathrm{pH} 4.0$ ) buffer. Unbound proteins were washed with sodium acetate until the absorbance returned to baseline. Adsorbed proteins were eluted with $0.2 \mathrm{M}$ ammonium acetate buffer ( $\mathrm{pH}$ 5.2). Fractions ( $1 \mathrm{ml}$ ) were collected and their absorbance was monitored at $280 \mathrm{~nm}$ using a spectrophotometer (UV-160A, Shimadzu, Japan). Protein fractions were freeze-dried, resuspended in $50 \mu \mathrm{l}$ of sterile deionized water containing $0.01 \%$ acetic acid and tested for antibacterial activity.

\section{Anti-bacterial activity of peak-II fraction of cation-exchange chromatography analyzed by zone of inhibition assay}

Antibacterial activity of peak-II fraction obtained on ion-exchange chromatography was assessed by a two-layer radial diffusion method described earlier by Mandar et al. [16]. Briefly, the modified protocol involves preparing a $14-\mathrm{ml}$ bacterial underlay of $1 \%$ agarose in $10 \%$ MH broth supplemented with $0.02 \%$ Tween in a 12 X $12 \mathrm{~cm}$ Petri dish. The agar was seeded with 1 X $10^{6}$ washed bacteria. Wells of $3 \mathrm{~mm}$ diameter were punched into the agarose and $50 \mu \mathrm{l}$ of the test sample were pipetted into each well. Negative controls comprised only sterile deionized water containing $0.01 \%$ acetic acid. The plates were incubated at $4^{\circ} \mathrm{C}$ for $3 \mathrm{~h}$ and then overlaid with $14 \mathrm{ml}$ vol. of sterile $1 \%$ agarose containing double strength Luria-Bertani Broth (LBB). They were incubated for a further $24 \mathrm{~h}$ at $35^{\circ} \mathrm{C}$. Clear zones in the agar underlay were taken as indicating antibacterial activity. The diameters of zones were measured and activity was expressed as clear zone area $\left(\right.$ in $\mathrm{mm}^{2}$ ) minus the area of the well.

\section{Reverse-phase HPLC (RP-HPLC)}

RP- HPLC was used to determine whether or not CpG-ODN-2006 challenge lead to the induction of new AMPs proteins. The pooled and lyophilized peak-II fraction of both control and CpG-ODN administered samples obtained on cation-exchange chromatography were resuspended in $500 \mu \mathrm{l}$ of solvent A $(0.1 \%$ trifluoroacetic acid (TFA) in water (v/v), and loaded onto a C18 RP-HPLC column using Dionex system (Hesperia, CA, USA) (Vydac., $4.6 \times 250 \mathrm{~mm}$, i.d; particle 
Citation: Reddy KVR, Deva S, Aranha C, Patgaonkar MS, Bhonde G (2011) Identification and Characterization of Molecules Having Anti-microbial Activities from Rabbit Epididymis Using Proteomic Approach. J Microbial Biochem Technol S2:002. doi:10.4172/1948-5948.S2-002

Page 3 of 11

size, $5 \mu \mathrm{m})$. Bound proteins were eluted at a flow rate of $1 \mathrm{ml} / \mathrm{min}$ in a three-step gradient of $0.1 \%$ trifluoroacetic acid /water and $0.1 \%(\mathrm{v} / \mathrm{v})$ trifluoro acetic acid in 50\% acetonitrile: $0-100 \%$ (45 min) held at 100\% for $5 \mathrm{~min}$ and brought back to $0 \%(100-0 \%)$. The absorbance of the eluted fractions was monitored at $220 \mathrm{~nm}$ using spectrophotometer (Shimadzu, UV-160, and Japan). To obtain sufficient amounts of active protein, purification was repeated at least 60-70 times and used for biotinylation and for various other studies. Pooled 1-5 peaks of control and $\mathrm{CpG}-\mathrm{ODN}$ induced samples were vacuum dried (Speed vac, Christ, USA) and subjected to Tricine SDS-PAGE

\section{Tricine-SDS-PAGE analysis of RP-HPLC fractions}

To determine the pattern of protein profiles, pooled RP-HPLC factions of control and CpG-ODN induced epididymal samples were subjected to Tricine Sodium Dodecyl Sulphate-Polyacrylamide Gel Electrophoresis (Tricine SDS-PAGE) as per the procedure described [16] .The gels were stained with Coomassie blue (Coomassie Brilliant blue R-250; Sigma) and calibrated using molecular weight markers (Amersham Bioscience, USA).

\section{Identification of HIV binding proteins of cation-exchange chromatography fractions by Far Western blotting approach}

Far Western blotting (FWB) approach has been used in the past to study protein-protein interactions [19]. Briefly, in the protocol we used a non-antibody protein probe to detect interacting proteins immobilized on a membrane support. Sine the amount of protein obtained after RP-HPLC was not sufficient enough for biotinylation, the peak-II pooled protein fraction obtained on cation-exchange chromatography was and labeled with biotin and identified molecules that are interactive to HIV proteins (gp120,gp17, gp41, p24). HIV strips (MP Diagnostics, India) were incubated with non-fat dry milk (NFDM) for $1 \mathrm{~h}$ at room temperature to block non specific binding sites. After two washings with Milli Q water, blots were incubated for $2 \mathrm{~h}$ at $37^{\circ} \mathrm{C}$ with biotinylated epididymal proteins. After two washings with Milli $\mathrm{Q}$ water, strips were incubated for $1 \mathrm{~h}$ with streptavidin conjugated horse redox peroxidase (HRP). After two washings, the strips were incubated with 3' 3-diaminobenzedine (DAB) and observed for binding by comparing with the standard HIV strip. The HIV protein blot to which the biotinylated proteins were bound showed a brown reaction. Each protein band corresponding to gp120, gp17, gp41, p24 was cut by keeping aside the standard HIV protein blot. The biotinylated protein (s) that bound to the HIV antigen strip were eluted with high salt buffer and dialyzed using $1 \mathrm{kDa}$ dialysis membrane against Milli $\mathrm{Q}$ water at $4^{\circ} \mathrm{C}$ overnight to remove salts. The dialyzed samples were precipitated by adding chilled acetone and concentrated. To rule out whether the HIV proteins of the blot bleached along with the biotinylated proteins, the blots were reprobed with goat anti-human secondary antibody conjugated to HRP. After two washings with Milli Q water, the strips were incubated with 3'-3 DAB and compared the intensity of brown color with the fresh strips processed in the same manner. Care was taken as much as possible to preserve the native conformation and interaction conditions for the proteins under study. Though the protocol is lengthy and requires a meticulous analysis, but at the end it gave us satisfactory results. The experiment was repeated at least 2530 times to get enough amount of the protein. The isolated protein/s was separated by 2-Dimentional polyacrylamide gel electrophoresis (2D-PAGE)

\section{Analysis of 2D-PAGE}

Aliquots of $50 \mu \mathrm{g}$ protein sample were diluted in $300 \mathrm{ml}$ rehydration buffer containing $8 \mathrm{M}$ urea, $2 \% \mathrm{~m} / \mathrm{v}$ CHAPS, $25 \mathrm{mM}$ dithiothreitol, $0.2 \%$ Biolyte (3-10 pI range), and $0.002 \%$ bromophenol blue. The sample was then applied onto a $17 \mathrm{~cm}$ immobilized $\mathrm{pH}$ gradient strip with a linear range of $\mathrm{pH} 3-10$, overlayed with mineral oil. Firstdimension IEF was performed using Bio-Rad iso-electro focusing (IEF) system. The voltage gradient was standardized and set from 50 volts to 6000 volts. After $18 \mathrm{~h}$ run, the strips were removed and placed in equilibration buffer, with dithiotheritol (DTT) and iodoacetamide for $30 \mathrm{~min}$ in each reagent. After equilibrating and alkylating, the electrophoresed strips were sealed onto the top of the seconddimension gels ( $12 \%$ SDS- polyacrylamide gel) with $0.5 \%$ agarose. The protein spots obtained were subjected to MALDI-TOF-MS. The $2 \mathrm{D}$ experiment was repeated twice to confirm the spot patterns before proceeding with further analysis. Replicates were scanned with a GS800 calibrated densitometer using standardized parameters, and gel images were processed by PDQuest 7.2.0 software. Spot densities were determined after normalization, based on the total spot volumes on the gel. Protein spots, with significant changes in densities (paired t-test, $\mathrm{P}$ $<0.05$ ) in a consistent direction (increase or decrease), were considered to be different and selected for further identification.

\section{In-gel tryptic digestion and peptide extraction}

The Selected protein spots from the stained gel were perfectly aligned with the bands on the adjacent blots and individual protein spots of interest were manually excised from the silver-stained gels in duplicate. BSA gel plugs were used as a protein standard for each set of in-gel tryptic digestion experiment. The gel bands were destained using a 1:1 mixture of $30 \mathrm{mM}$ potassium ferricyanide and 100 $\mathrm{mM}$ sodium thiosulfate. The protein bands were typically digested according to the protocol described earlier by Shevchenko et al. [20] with minor modifications, using sequencing grade trypsin $0.01 \mu \mathrm{g}$ / $\mu \mathrm{l}$ (Applied Biosystems) for $16 \mathrm{~h}$ at $37^{\circ} \mathrm{C}$. The tryptic peptides were extracted with trifluoroacetic acid (TFA). The extracts were pooled and dried completely by centrifugal lyophilization. The peptides were reconstituted in sample diluent and mixed with an equal volume of matrix ( $\alpha$-cyano-4-hydroxycinnamic acid, $10 \mathrm{mg} / \mathrm{ml}$ in $70 \% \mathrm{v} / \mathrm{v} \mathrm{ACN}$, $1 \% \mathrm{v} / \mathrm{v}$ TFA) and spotted in duplicate on a target plate and allowed to air dry. Trypsin digested $\beta$-galactosidase Escherichia coli ( $\beta$-gal) and CHCA mixture was also spotted on MALDI plate and used as a known standard for each set of MS analysis. Peptides were analyzed by MALDI-TOF/TOF

\section{MALDI-TOF Mass spectrometric analysis}

All the proteomics work reported in this paper was carried out at central proteomics facility of National Institute for research in Reproductive Health (NIRRH). Mass spectrometry analyses were performed using the Applied Biosystems 4700 Proteomics Analyzer (MALDI-TOF-TOF; Foster City, CA, USA) in reslector mode for positive ion detection. The laser wavelength was $355 \mathrm{~nm}$. All the MS spectra resulted from accumulation of at least 1000 laser shots. MALDI target plate was internally calibrated and default updated using the $[\mathrm{M}+\mathrm{H}]$ ion from 4700 proteomics analyzer calibration mixture $(4700$ Cal Mix, Applied Biosystems) as per the manufacturer's instructions. $\beta$ gal ( $\beta$-galactosidase digested), a known standard, was used to validate mass accuracy of mass spectrometer. In case of samples, the mass spectra were calibrated using the three trypsin auto digest products: fragment 92-99 $\left([\mathrm{M}+\mathrm{H}]^{+}=805.416 \mathrm{Da}\right)$, fragment $50-69\left([\mathrm{M}+\mathrm{H}]^{+}=2163.056 \mathrm{Da}\right)$, and fragment $70-89\left([\mathrm{M}+\mathrm{H}]^{+}=2273.159 \mathrm{Da}\right)$. 
Citation: Reddy KVR, Deva S, Aranha C, Patgaonkar MS, Bhonde G (2011) Identification and Characterization of Molecules Having Anti-microbial Activities from Rabbit Epididymis Using Proteomic Approach. J Microbial Biochem Technol S2:002. doi:10.4172/1948-5948.S2-002

Page 4 of 11

\section{MALDI-TOF-MS data analysis}

Combined MS and MS/MS spectra were used to search against the taxonomy Mammalia using the GPS software (version 3.5, Applied Biosystems) running Mascot search algorithm. The isoelectric point (pI) of the identified proteins/peptides was predicted using the Expert Protein Analysis System (ExPASY online software (produced by Molecular Biology of the University of Geneva service station). All peptides with scores less than the identity threshold $(\mathrm{p}=0.05)$ or a rank less than one were not considered. The criteria used to accept identifications included the number of peptides matched, and the Probability Based Mowse Score (PBMS > 35). Proteins having origin of rabbit and molecular weight estimated from the gel slice was additional requirements for protein identification. A protein was accepted into the list if it was confidently identified in the sample with more than two highly confident peptide hits. If necessary, peptides were excluded if their masses corresponded to those for trypsin, and keratins or to other irrelevant proteins. The sequence which has highest PBMS value was selected for further characterization

\section{Sequence alignment of hemoglobin- $\beta$ subunit from different mammals}

The amino acid sequence of $\beta$-hemoglobin of rabbit, bovine, human and mouse were aligned with bio-software Lasergene 6 program. The MegAlign module of the Lasergene 6 displayed the difference among these sequences. In Figure 6, we compared the amino acid sequences of $\mathrm{Hb}-\beta$ of rabbit with human, bovine and mice.

\section{Design and synthesis of peptides and antibody production}

A 29 mer linear peptide, REHb $\beta$ P was synthesized commercially by standard F-moc (N-(9-fluorenyl) methoxycarbonyl) chemistry. REHb $\beta$ P had an overall charge of +4 . The peptide was purified via analytical RP- HPLC on C18 column (USV peptide synthesis facility, Mumbai, India). To raise anti-peptide polyclonal antibody, REHb $\beta \mathrm{P}$ was coupled with a keyhole limpet hemocyanin carrier (KLH) (Pierce, Rockford, IL, USA) according to manufacturer's instructions. Two rats were intradermally immunized with $100 \mu \mathrm{l}$ of PBS containing 25 $\mu \mathrm{g}$ of the peptide emulsified in $50 \mu \mathrm{l}$ complete Freunds adjuvant. The first immunization was followed by two boosts at 2 -week intervals with aliquots of peptide emulsified in incomplete Freunds adjuvant. Anti-serum was collected 10 days after the last injection and titers were checked by ELISA. The anti-peptide antibody was purified via affinity chromatography over a sepharose column conjugated with REHb $\beta \mathrm{P}$ used as an immunogen.

\section{Circular dichroism}

Circular Dichroism (CD) spectra were collected using a Jasco J-720 spectropolarimeter available at our Institute Central equipment facility. Spectral scan was performed from 250 to $195 \mathrm{~nm}$, with step resolution of $0.1 \mathrm{~nm}$ and bandwidth of $1.0 \mathrm{~nm}$ at speed $50 \mathrm{~nm} / \mathrm{min}$ [21]. A 1-mm path length quartz cuvette was used for the measurements, and values from 3 scans were averaged per sample. Freshly prepared peptide samples were measured at $40 \mu \mathrm{m}$. The sodium phosphate buffer ( $\mathrm{pH}$ 7.4) was used as a solvent for measurements, and its background was subtracted from actual sample values. The molar ellipticity was calculated using the equation, $[\theta n] 222=-39,500 X(1-2.57 / n)$, where $\mathrm{n}=$ number of residues.

\section{Radial diffusion assay}

The antibacterial activity of cation-exchange and RP-HPLC purified fractions were tested in radial diffusion assay (RDA) against $E$. coli and S.aureus at neutral $\mathrm{pH}$ (pH: 7) as described earlier [16].

\section{Determination of the minimal inhibitory concentrations (MICs)}

The antibacterial activity of synthesized peptide, REHb $\beta \mathrm{P}$ was determined against Candida albicans, gram negative bacteria (Escherichia coli and Pseudomonas aeruginosa) and gram positive bacteria (Staphylococcus aureus and Streptococcus pyogenes) was evaluated as described by Mandar et al. [16]. Briefly, overnight grown bacterial cultures in TSB were diluted with medium to obtain $\sim 1 \times 10^{8}$ $\mathrm{cfu} / \mathrm{ml}$ and then diluted to $\sim 1 \times 10^{6} \mathrm{cfu} / \mathrm{ml}$ using MHB, and incubated in serial two fold dilutions of $\operatorname{REHb} \beta \mathrm{P}(1.89-60.61 \mu \mathrm{M})$, after which the bacteria was washed. About $10 \mu \mathrm{l}$ aliquots were removed at $30 \mathrm{~min}$, diluted 1:1000 in growth medium and spread on $\mathrm{MH}$ agar plates to quantify the number of cfu survived by counting the average number of surviving $\mathrm{cfu} / \mathrm{ml}$ in the presence of peptide. As a control, $10 \mu \mathrm{l}$ of PBS was incubated with each strain bacterial culture.

\section{Preparation of small unilamellar phospholipid vesicles}

To elucidate the ability of $\mathrm{REHb} \beta \mathrm{P}$ to permeabilize bacterial cell membranes, a dye leakage assay with liposome was performed. Liposomes mimicking negatively charged microbial membranes were prepared as described earlier [22]. To a suspension of calcein-loaded liposomes, two fold serial dilutions of REHb $\beta$ P $(1.89-60.61 \mu \mathrm{m})$ were added and incubated 1-5 min. Time dependent changes in fluorescence intensities were determined as a percentage of the maximal fluorescence intensity obtained after total lysis of the liposomes by 4 $\mu \mathrm{l}$ of $0.1 \%(\mathrm{v} / \mathrm{v})$ Triton X-100. Peptide induced calcein fluorescence dye leakage was monitored continuously over time at excitation and emission wavelengths of $494 \mathrm{~nm}$ and $520 \mathrm{~nm}$ respectively, on an FLX 800 microplate spectrofluorometer.

\section{Binding studies of REHb $\beta$ P to gp120}

The binding affinity of REHb $\beta$ P with gp 120 was evaluated by ELISA. Briefly, 96 well plate was coated with gp120 $(1 \mu \mathrm{g} / \mathrm{well})$ and incubate over night at $4^{\circ} \mathrm{C}$. Wells were washed with PBS and nonspecific binding was blocked with blocking solution (1\% BSA in PBS) by incubating for $1 \mathrm{hr}$ at $37^{\circ} \mathrm{C}$. After two washes with $0.1 \%$ PBS-T20, two fold serial dilutions of REHb $\beta \mathrm{P}(1.89-60.61 \mu \mathrm{M})$ was incubate at $37^{\circ} \mathrm{C}$ for $2 \mathrm{~h}$ (wells with out peptide were also run simultaneously and treated as controls). After two washes with $0.1 \%$ PBS-T20, anti- REHb $\beta$ P antibody was added at a dilution of $1 / 100$ and incubated for $1 \mathrm{~h}$ at $37^{\circ} \mathrm{C}$. Pre-immune serum controls were also maintained to check the nonspecific activity. After two washes with $0.1 \%$ PBS-T20 goat anti rat secondary antibody (1:500) was added and incubated at $37^{\circ} \mathrm{C}$ for $1 \mathrm{hr}$. Plate was washed with PBS and Ortho-phenylinediamine (OPD) was added and kept in dark or $15 \mathrm{~min}$. Finally the reaction stopped using $100 \mu \mathrm{l}$ of $4 \mathrm{~N} \mathrm{H} 2 \mathrm{SO} 4$. The brown color was read at $490 \mathrm{~nm}$ using ELISA reader.

\section{Cell-based luciferase reporter gene fusion assay}

HeLa-derived HL2/3 (effector) cells, which express the HIV-1 Env on surface and Tat protein in their cytoplasms were co-cultured with TZM-bl cells (Target/indicator $)$ at a 1:1 cell density ratio $(2.5 \times 104$ cells/well ) in order to examine whether the peptide interfered with the binding process of HIV-1 Env and the CD4 receptor as described earlier [23]. Briefly., co-cultures were incubated for $48 \mathrm{~h}$ in the absence or presence of two-fold serial dilutions of REHb $\beta P(1.89-60.61 \mu \mathrm{M})$ and trimeris $(0.312-10 \mu \mathrm{g})$ of (N-acetyl-YTSLIHSLIEESQNQQEKNEQ ELLELDKWASLWNWF-CONH2) (+ ve control for inhibition). Upon 
fusion of both cell lines, the Tat protein from HL2/3 cells activates luciferase reporter gene expression in TZM-bl-CD4-LTR-LUC cells. Efficiency of fusion was determined by measuring luciferase activity in the wells following the instructions of the manufacturer using the bright-glow luciferase determination kit (Promega, Madison, USA). The percentage of inhibition of HL2/3-TZM-bl-CD4 cell fusion was calculated with respect to the positive control of untreated cells. Light intensity was measured using Luminometer. Background fluorescence in TZM-bl cells was obtained without the addition of HL2/3 cells.

\section{Indirect Immunofluorescence (IIF)}

Tissue samples were obtained from rabbit epididymis, and snap frozen with Tissue-Tek optimal cutting temperature (OCT) compound (Sigma). The cauda epididymis was cut into $5 \mathrm{~mm}$ thick frozen sections. Rabbit semen was collected by artificial vagina as described earlier [24] and smeared onto clean glass slides. Tissue sections and sperm slides were fixed in ice-cold acetone for $30 \mathrm{~min}$, and then blocked with 5\% BSA in PBS for $30 \mathrm{~min}$ at room temperature, and later incubated either with anti-rat REHb $\beta$ P antibody (1:100 dilution) in PBS overnight at $4^{\circ} \mathrm{C}$ or with normal rat IgG (1:500 dilution) as control. Samples were washed with PBS and incubated with a secondary goat anti-rat antibody linked with fluorescein isothiocyanate (1:500 dilution; Sigma) for $1 \mathrm{~h}$ at $37^{\circ} \mathrm{C}$. Digital photographs of fluorescent sections were viewed under a laser scanning confocal microscope (Carl Zeiss LSM-510; Carl Zeiss

(a)

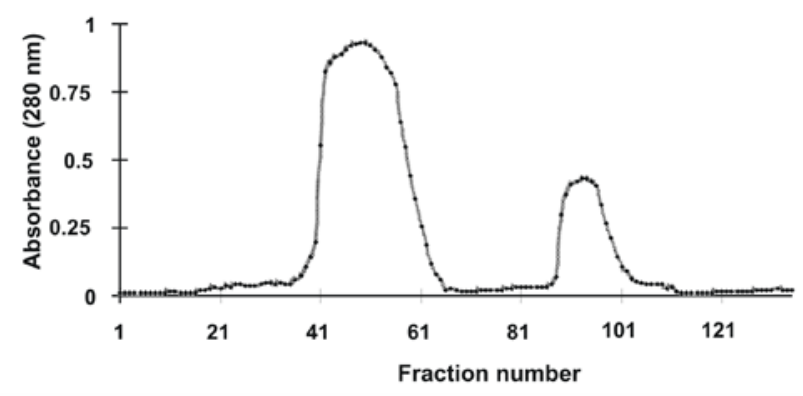

(b)

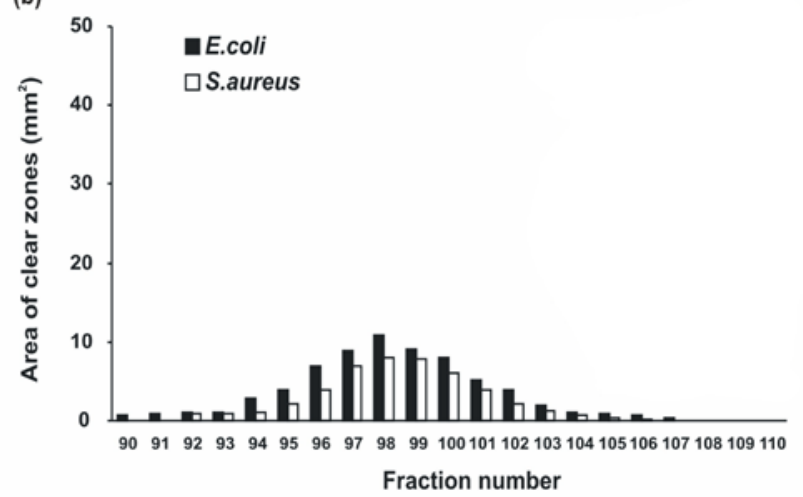

Figure 1: Protein profiles of dialyzed epididymal lystates of rabbit applied onto a $\mathrm{CMC}$ column. Elution pattern of $\leq 30 \mathrm{kDa}$ proteins, concentrated by ultrafiltation (a). Unbound fractions were washed with $0.2 \mathrm{M}$ sodium acetate ( $1 \mathrm{ml}$ fractions) until $\sim 110 \mathrm{ml}$ of buffer passed through the column. Bound fractions were eluted with $0.2 \mathrm{M}$ ammonium acetate. (b) Antimicrobial activity of fractions were tested against $E$. coli and $S$. aureus by radial diffusion assay and expressed as area of inhibition $\left(\mathrm{mm}^{2}\right)$.
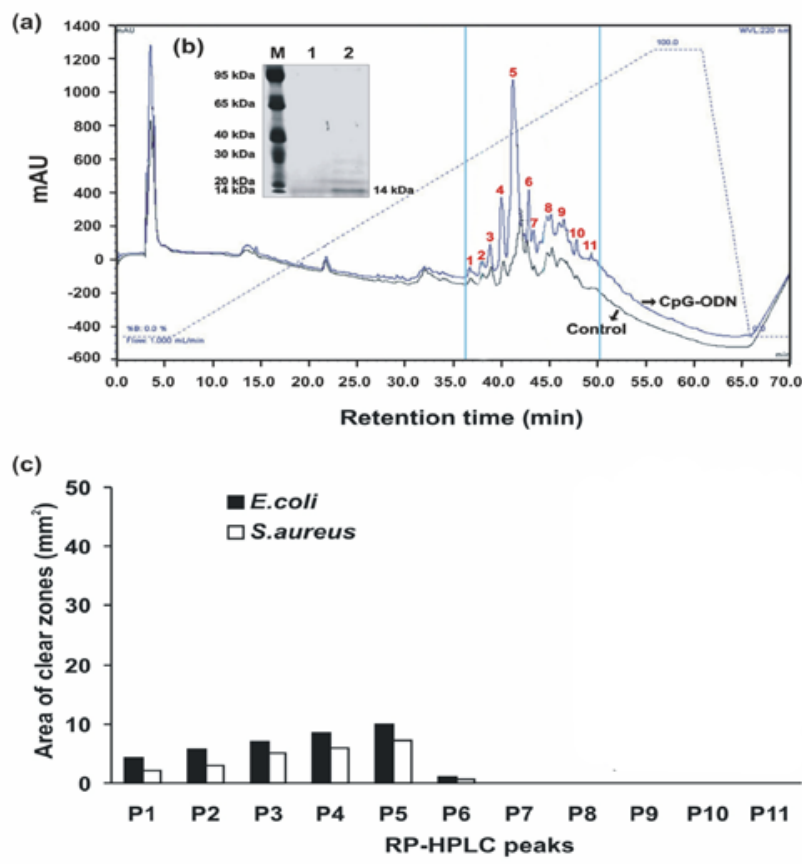

Figure 2: Peak-II fractions obtained on cation-exchange chromatography separated on a Vydac C8 RP-HPLC column equilibrated with $0.1 \%(\mathrm{v} / \mathrm{v})$ TFA / water. (a) Elution ( $1 \mathrm{ml} / \mathrm{min}$ ) was performed according to the procedure described in the material and methods section. (b)The active pooled fractions (peaks-1 to 5) showed four protein bands at 15, 17, 22 and $27 \mathrm{kDa}$ region on SDS-PAGE (Lane 1= uninduced and $2=$ induced pooled fractions Peaks 1-5 demonstrated antimicrobial activity as tested by radial diffusion assay against $E$. coli and S. aureus (c).Protein obtained from several runs were pooled peak wise and antimicrobial activity was shown against $E$. coli and $S$. aureus.

Vision, Germany). This study was carried out at Central Equipment Facility of NIRRH, Mumbai, India.

\section{Hemolysis assay}

The effect of REHb $\beta \mathrm{P}$ on RBCs was determined using freshly isolated rabbit erythrocytes [24]. Briefly, aliquots of erythrocyte suspension $\left(10^{6}\right.$ cells/microfuge tube) were incubated at $37^{\circ} \mathrm{C}$ for 60 min along with twofold serial dilutions of peptides $(0.47-60.61 \mu \mathrm{m})$. The hemoglobin release was monitored by measuring absorbance at A450 on a microplate reader (Bio-Tek Instruments Inc., Winooski, VT). $100 \%$ hemolysis was determined with $4 \mu$ of $0.1 \%$ Triton X-100.

\section{Cell viability assay}

Cytotoxic effects of REHb $\beta$ P on immortalized human endocervical cells (End1/E6E7 cells) (Gift from Dr. Raina Fichorova, Harward Medical school, Boston, USA) and rabbit erythrocytes were determined using KineticBlue reagent (Krishgen Biosystems, India). End1/E6E7 cells were grown in keratinocyte serum medium (Invitrogen, USA). Exponentially growing End1/E6E7 cells were seeded into a sterile tissue culture 96-well plates at a density of $10^{6}$ cells/well and incubated for $24 \mathrm{rs} \mathrm{h}$ at $37^{\circ} \mathrm{C}$ prior to exposure to two fold serial dilutions of peptide in DMEM medium $(1.89-60.61 \mu \mathrm{m})$. Plates were incubated for $3 \mathrm{hrs}$ before adding KineticBlue reagent as described [24].

\section{Statistical analysis}

The antimicrobial assays were performed using the same batch of REHb $\beta$ P. Data analysis for each microbe was carried out using one- 
way ANOVA. Zones of growth inhibition were measured and the width of the well subtracted prior to calculations. CFU/ml for each sample was calculated by multiplying the number of colonies counted by the dilution factor. Data points in all experiments were performed in triplicate to obtain valid statistical evaluation of the results.

\section{Results}

\section{Identification of AMPs}

To identify the molecules having antimicrobial activities, we intended to isolate AMPs from the epididymis of rabbit that are expressed along the tissue and secreted into the lumen. Our initial efforts in the identification of AMPs could not yield satisfactory results. Therefore, in order to induce the constitutively expressed proteins and/or synthesis of new defense molecules, rabbit epididymis were challenged under ex vivo with CpG ODN-2006. The schematic presentation of purification protocol is depicted in supplemented data (Figure 1).

\section{CpG-ODN induces antimicrobial defense molecules in rabbit epididymis}

Freshly prepared rabbit epididymal tissue homogenates from both control and CpG-ODN induced epididymal tissue were mixed separately with $0.01 \%$ acetic acid and fractionated on a CMC cation exchange resin. Fractions $(1 \mathrm{ml})$ were eluted in $0.2 \mathrm{M}$ ammonium acetate. Two peaks were obtained. The peak-I was the non-cationic peak, while the peak-II was the cationic. Fractions of peak-I exhibited no antibacterial ability (data not shown). Fractions $94-104$ of peak-II were found to contain detectable growth inhibiting activity against $E$. coli and S.aureus as demonstrated by radial diffusion assay (supplemented

\begin{tabular}{|c|c|c|}
\hline Sr. No. & $\begin{array}{l}\text { Far Western blotting } \\
\text { (Saline administered) }\end{array}$ & $\begin{array}{c}\text { Far Western blotting } \\
\text { (CpG-ODN administered) }\end{array}$ \\
\hline 1 & $\beta$-defensin-5 & $\beta$-defensin-5 * \\
\hline 2 & Lysozyme & Lysozyme \\
\hline 3 & $\begin{array}{l}\text { Triose phosphate } \\
\text { dehydrogenase-1 }\end{array}$ & $\begin{array}{l}\text { Triose phosphate } \\
\text { dehydrogenase- } 1\end{array}$ \\
\hline 4 & Hemoglobin a-subunit & Hemoglobin $\alpha$-subunit * \\
\hline 5 & Calreticulin & Calreticulin * \\
\hline 6 & Calgranulin & Calgranulin \\
\hline 7 & Calcyclin & Calcyclin \\
\hline 8 & Calpain & - \\
\hline 9 & Histone-H4 & Histone-H4 * \\
\hline 10 & Transthyretin & Transthyretin \\
\hline 11 & Hemoglobin $\beta$-subunit & Hemoglobin $\beta$-subunit * \\
\hline 12 & Lactate dehydrogenase & Lactate dehydrogenase \\
\hline 13 & Epididymal secretary protein-1 & Epididymal secretary protein-1 \\
\hline 14 & Laminin & Laminin \\
\hline 15 & Keratin-10 & Keratin-10 \\
\hline 16 & Trypsin & Trypsin \\
\hline 17 & Eipdidymal secretory protein-1 & - \\
\hline 18 & Myelin basic protein (MBP) & Myelin basic protein (MBP) \\
\hline 19 & Fetuin & Fetuin \\
\hline 20 & Tropomyosin- $\alpha$ chain & - \\
\hline 21 & $\begin{array}{l}\text { 3-phosphoglycerate } \\
\text { dehydrogenase (PGD) }\end{array}$ & $\begin{array}{l}\text { 3-phosphoglycerate } \\
\text { dehydrogenase (PGD) }\end{array}$ \\
\hline
\end{tabular}

Table 1: Comparative Proteome Profiling of rabbit epididymal lysates analyzed by Conventional chromatographic and Far Western blotting methods before and after CpG-ODN-2006 challenged $\left({ }^{*}=\right.$ Proteins activated after CpG -ODN stimulation).

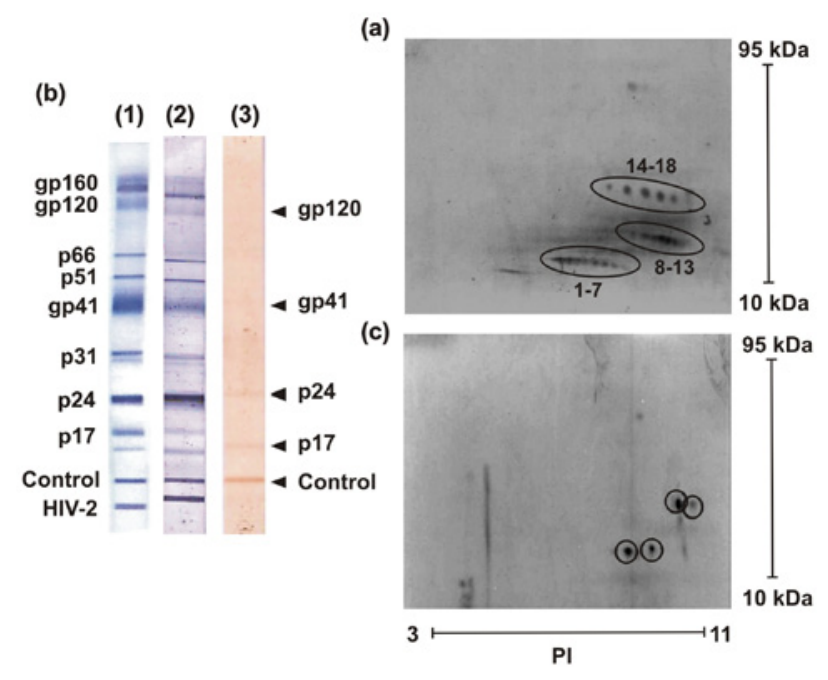

Figure 3: 2D-PAGE map of rabbit epididymal RP-HPLC purified pooled fractions (peaks 1-5) (a). Eighteen spots were observed. Peak-II pooled fractions obtained on cation exchange chromatography labelled with biotin and allowed to interact with HIV antigens on nitrocellulose blots and compared with standard HIV blot (b-1) and positive control (b-2). Biotin labeled proteins bound to HIV strip (b-3) were eluted as described in material and methods section and subjected to 2D-PAGE. Four spots were observed (c).

Figure 2a, b). These fractions were pooled, lyophilized, reconstituted with $0.1 \%$ TFA and further purfied by RP-HPLC using $\mathrm{C}_{8}$ column.

\section{Reverse-phase HPLC purification of AMPs}

RP-HPLC purification of peak-II protein fraction obtained on cation-exchange chromatography from CpG-ODN2006 challenged (10 $\mu \mathrm{g} / \mathrm{gm}$ tissue) rabbit epididymis showed, stimulation could induce the synthesis of few new proteins as well as up-regulation of some of the constitutively expressed proteins as compared to the control. The proteins were eluted in a three-step gradient as mentioned in materials and methods. The purification was repeated at least 60-70 times to get enough amount of the protein. Based on the retention time, eleven protein peaks (P1-P11) were observed $(35,36,37,38,40,42,43,45,46$, 48 and 50). All the peaks were collected, lyophilized and tested against E.coli and S.aureus by radial diffusion assay. Peaks 1 to 5 demonstrated detectable amounts of antibacterial activity (supplemented figure 3a,b) were pooled and named as rabbit epididymal secretary anti-microbial protein (RESAMP). The RP-HPLC results were in agreement with SDSPAGE data, where we observed the induction of few low molecular weight proteins $(<30 \mathrm{kDa})$ with a mobility corresponding to $\sim 15$ to $27 \mathrm{kDa}$ as compared to the non-induced control. The silver stained gel showed the presence of a typical RP-HPLC elution pattern of control and stimulated samples.

\section{Separation of proteins by 2D-PAGE analysis}

RP-HPLC fractions from CpG-ODN induced and control epididymal samples were pooled and subjected to 2D-PAGE analysis. Eighteen polypeptide spots $<30 \mathrm{kDa}$ were visualized on 2D gel (Fig: 3a). These spots were cored and subjected to MALDI-TOF analysis to determine their identity. Peptide mass fingerprinting was performed with the Mascot search engine against the NCBI non-redundant protein data base for the species rabbit. Some of the proteins identified by MALDI-TOF showed identity with several known proteins (Table 
Citation: Reddy KVR, Deva S, Aranha C, Patgaonkar MS, Bhonde G (2011) Identification and Characterization of Molecules Having Anti-microbial Activities from Rabbit Epididymis Using Proteomic Approach. J Microbial Biochem Technol S2:002. doi:10.4172/1948-5948.S2-002

Page 7 of 11

1). At this point of time it was difficult for us to know which of the identified molecules which specifically interact with HIV antigens, hence we employed Far western blotting (FWB) technique.

\section{Far Western blotting method detected HIV antigens}

The results of FWB reveal that some of the biotinylated proteins interacted with HIV antigens such as gp120, p24, p41 and p17 (Figure $3 \mathrm{~b})$. Four spots $<30 \mathrm{kDa}$ were visualized on $2 \mathrm{D}$ gel (Figure $3 \mathrm{c}$ ).

\section{MALDI-TOF analysis}

When variations of densities were more than three times, four polypeptide spots were then successfully identified using MALDITOF/TOF mass spectrometry with MS/MS followed by database searching (Swiss-Prot protein database). We were able to identify several proteins with high confidence. However, four protein spots of $2 \mathrm{D}$ gel analyzed by MALDI-TOF/TOF representing seven proteins. Of the four spots, one spot had two protein matches (2 proteins i.e hemoglobin- $\alpha$ and $\beta$ peptides) while 1 spot gave a single match (1 protein i.e 3-phosphoglycerate dehydrogenase), and the remaining two spots gave two protein matches each (4 proteins) viz transthyretin, Triose phosphate dehydrogenase- 1 and Lactate dehydrogenase- $\beta$ and calreticulin. As summarized in Table 2, each of these proteins is characterized by its predicated MW, pI, mean fold, Swiss-Prot accession number, and regional abundance. Single entry search was performed to get more information about the identified proteins from National Center for Biotechnology Information (NCBI) database, Universal Protein Resource (UniProt) and Expert Protein Analysis System (Expasy) proteomics server of the Swiss Institute of Bioinformatics (SIB). The results suggests that, of the 21 peptide sequences identified by MALDI-TOF (Table 1), only four sequences belongs to hemoglobin- $\alpha$ and $\beta$ subunits, transthyretin and calreticulin protein respectively were reacted with HIV proteins (gp120, gp41, gp17 and p24). The proteins were tested against E.coli and S.aureus using MIC assay. Of the four proteins, $\mathrm{Hb}-\beta$ sub unit showed better activity against E.coli and $S$. aureus than the other three proteins (data not shown). Using bio-informatic tools, a domain interactive to gp120 has been identified within the $\mathrm{Hb}-\beta$. Interestingly, the domain is the part of the $\mathrm{Hb}-\beta$ peptide sequence identified by the MALDI-TOF. Therefore, all the studies reported here were carried out with the 29 mer peptide of $\mathrm{Hb}-\beta$ sub unit.

\section{Characterization of RESAMP fraction}

MALDI-TOF-MS results of the RESAMP demonstrates that one of the proteins of the RESAMP identified showed highest Probability
Based Mowse Score (PBMS) of 99, which corresponds to110-124 (LVIVLSHHFGKEFTP) residues of the $\mathrm{Hb}-\beta$ chain. Using AMP Database (http://aps.unmc.edu/AP/main.php) and bioinformatics tools, we synthesized a 29 mer peptide i.e REHb $\beta$ P with a net positive charge of +4 , hydrophobicity of $45 \%$ and $\mathrm{pI}$ value of 8.1 (supplemented figure. 4). The $\beta$ and $\alpha$ regions, and Kyte-doo-little plot of the $\mathrm{Hb}$ were depicted by the Protean module of the Lasergene 6 (supplemented figs. 5 a \& b). Approximately 50-60 amino acid in rabbit $\mathrm{Hb}-\alpha / \beta$ were associated with microbicidal activity and form $\alpha$-helical and $\beta$-sheet structures. Based on the predicted analysis of the $\beta$-chain of the rabbit $\mathrm{Hb}$, the peptide is in the highest hydrophobic region. These indicate that hydrophobicity of the peptide is related to its antibacterial activity.

\section{Tricine-SDS-PAGE of RESAMP and REHb $\beta P$}

The RESAMP that affected the growth of E. coli and S.aureus was resolved on Tricine-SDS-PAGE and determined the molecular weights. RESAMP showed 4 protein bands $(<30 \mathrm{kDa}$ ) corresponding to 15,17 , 22 and $27 \mathrm{kDa}$ (Figure $2 \mathrm{~b}$ ).

\section{Circular Dichroism (CD)}

Circular dichroism (CD) was used to determine the secondary structure of the REHb $\beta \mathrm{P}$ and to predict whether the peptide exhibit antibacterial activity. Results showed that REHb $\beta$ P is largely a $\alpha$-helical and $\beta$-sheet structure in sodium phosphate buffer ( $\mathrm{pH} 7.4$ ), which proved to be essential for its antimicrobial activity (data not shown). These results are in conformity with the prediction analysis obtained using Protean module Lasergene-6 software.

\section{Binding of REHb $\beta$ P with gp 120}

The interaction of REHb $\beta$ P with gp120 was confirmed by gp120 binding assay using ELISA. The results revealed that REHb $\beta \mathrm{P}$ bound to gp120 in a dose dependent fashion, suggesting the peptide might be having anti-HIV properties (Figure 4).

\section{Luciferase reporter fusion assay to determine the anti-HIV potential of REHb $\beta P$}

A cell-based fusion assay was used to mimic the gp120-CD4mediated fusion process of HIV-1 to the host cells. Fusion efficiency between HL2/3 and TZM-bl cells was monitored based on activation of HIV-LTR-driven luciferase cassette in TZM-bl cells by HIV-1 Tat from the HL2/3 cells. The results indicated that TZM-bl -CD4-LTRLuc cells fused as the result of the gp120-CD4 interaction, and the

\begin{tabular}{|c|c|c|c|c|c|c|}
\hline Peptide count & Protein ID & Name & $\begin{array}{l}\text { Mol. Wt. } \\
\text { (kDa) }\end{array}$ & PI & Mowse Score & Function \\
\hline 7 & HBA_RABIT & Hemoglobin subunit $\alpha-1 / 2$ & 15.51 & 8.07 & 71 & Oxygen Transport and antimicrobial \\
\hline 10 & HBB_RABIT & Hemoglobin subunit $\beta-1 / 2$ & 15.95 & 8.06 & 99 & Oxygen Transport and antimicrobial \\
\hline 5 & 146521 & Titin & 110 & 7.3 & 44 & Muscle formation and elasticity \\
\hline 5 & CALR_RABIT & Calreticulin & 7.900 & 4.33 & 60 & Epididymal sperm maturation and anti-bacterial \\
\hline 4 & JC1462 & Neutrophil peptide - N5 & 3.551 & 9.01 & 78 & Anti-bacterial* \\
\hline 2 & TTHY_RABIT & Transthyretin & 13.66 & 5.79 & 45 & Thyroid hormone-binding protein \\
\hline 2 & LDHA_RABIT & Lactate dehydrogenase $\mathrm{A}$ & 36.56 & 8.17 & 37 & Spermatogenesis and sperm maturation \\
\hline 4 & TPM1_RABIT & Tropomyosin $\alpha-1$ chain & 32.68 & 4.690 & 39 & $\begin{array}{l}\text { cytoskeleton interacting proteins binds to } \\
\text { muscle actin filaments }\end{array}$ \\
\hline
\end{tabular}

Table 2: Comparative Proteome Profiling of rabbit epididymal protein extracts analyzed by proteomic approach consisting of 2D, Far Western blotting and MALDI-TOF-MS 
amount of fused cells were measured with the Luciferase reporter gene fusion assay. In the presence of REHb $\beta$, the fusion of HL2/3 with TZM-bl cells efficiently blocked $(\mathrm{P}<0.001)$ between both cells in a dosedependent manner, suggesting REHb $\beta$ P may have anti-HIV potential in in vitro (Figure 5). However, these observations being confirmed by p24 antigen assay.

\section{REHb $\beta P$ Inhibits the growth of various clinical pathogens}

The results of antibacterial activity of $\mathrm{REHb} \beta \mathrm{P}$ against gram negative bacteria (E. coli and $P$. aeruginosa) and gram positive organisms ( $S$. aureus and $S$. pyogenes) demonstrates an increased susceptibility of these organisms to the peptide and the effect was found to be dose dependent. E. coli and P. aeruginosa seem to be more susceptible to the peptide than $S$. aureus and $S$. pyogenes (Figure 6). The higher susceptibility of gram negative bacteria as compared to the gram positive bacteria clearly indicates the possibility of REHb $\beta \mathrm{P}$ being target specific (e.g. against lipopolysaccharides) in respect to its antimicrobial activity. Similar experiments need to be performed with a broader panel of microorganisms including filamentous fungi, yeast and virus including HIV.

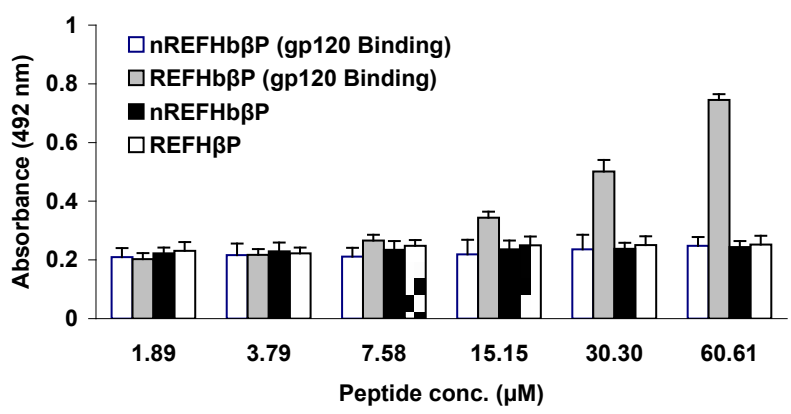

Figure 4: Determination of REFHbßP binding to gp120 by ELISA. REFHbßP bind to gp120 in a dose dependent fashion. Maximum binding was observed with $60.61 \mu \mathrm{M}$ of peptide. Each value is the mean \pm S.D of six individual observations obtained from three separate experiments performed on different days.

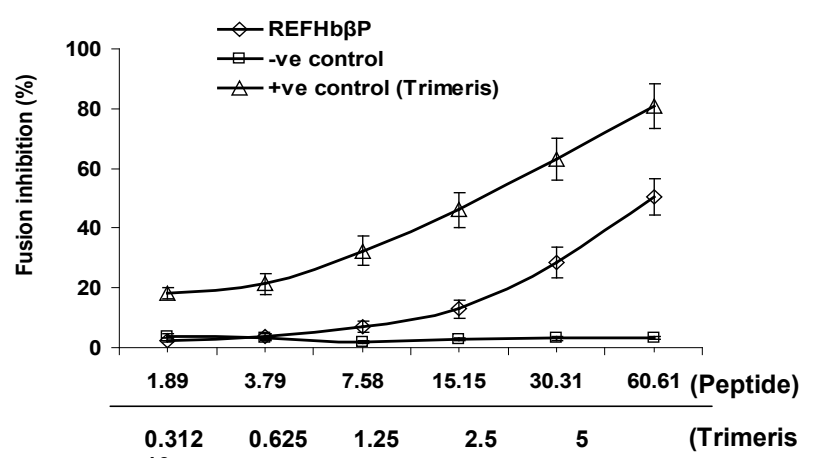

Figure 5: A cell-based fusion assay was used to mimic the gp120-CD4 mediated fusion of the viral and host cell membranes. HL2/3 and TZM-bI-CD4-LTR-Luc cells were incubated with a two-fold serial dilution of peptide, REFHbßP and a known antiretroviral compound, trimeris. Maximum inhibition was observed with $60.61 \mu \mathrm{M}$ of REFHbßP. The assay was performed in triplicate; the data points represent the mean \pm S.D of six individual observations obtained from three separate experiments performed on different days.

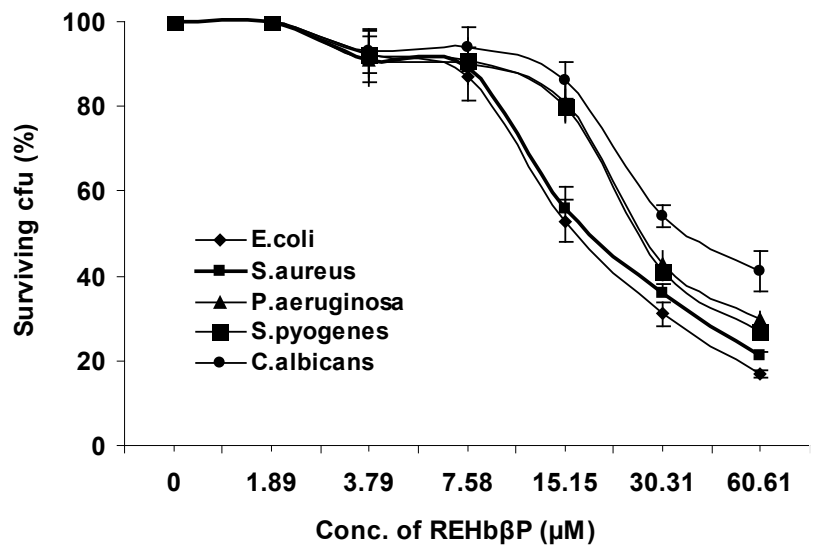

Figure 6: Effect of REHbßP on the growth inhibition of E.coli, S.aureus P.aeroginosa, S.pyogenis and C.albicans determined by MIC assay. Bacteria were incubated with indicated 2 fold serial dilution of REHbßP for $30 \mathrm{~min}$. The growth of bacteria was inhibited in a dose dependent fashion. The figure shown is a representative picture from three independent experiments performed on different days. Each value is the mean \pm S.D of six individual observations obtained from three separate experiments performed on different days.

\section{REHb $\beta P$ induces liposome membrane permiabilization}

The effect of REHb $\beta \mathrm{P}$ on the integrity of liposomes was studied using calcein-loaded liposomes. The release of calcein was measured as the 'dequenching' of the calcein fluorescence and monitored continuously. Following addition of REHb $\beta P(1.89-60.61 \mu \mathrm{m})$ an immediate increase in fluorescence was observed which was dose and time dependent. While a concentration of 30.30 and $60.61 \mu \mathrm{m}$ was able to cause maximum leakage $(\sim 70 \%)$ after 5 min of liposomes, lower concentrations of peptide demonstrated a leakage about $37 \%$ after 5 min of incubation. Addition of $0.1 \%$ Triton X-100 to the liposome suspension served as a positive control as it caused total (100\%) calcein release as determined from the fluorescence signal (Figure 7).

\section{REHb $\beta P$ did not damage rabbit erythrocytes}

Most natural peptides are cationic, and hence their interaction with anionic membrane phospholipids provides a ready explanation for their specificity for bacterial membranes. However, some AMPs exhibit hemolytic activities, and delivery of such peptides becomes problematic, and hence hemolytic activity of REHb $\beta \mathrm{P}$ was carried out. Rabbit erythrocyte suspension was incubated in the presence of two fold serial dilution of the peptide $(0.47-60.61 \mu \mathrm{M})$ for $60 \mathrm{~min}$. The peptide did not cause erythrocyte hemolysis at concentrations upto $30.31 \mu \mathrm{M}$. However, only a minor hemolytic activity (8-10\%) was observed at $60.61 \mu \mathrm{M}$ concentration (Data not shown).

\section{$\mathrm{REHb} \beta \mathrm{P}$ did not reduce human endocervical cell viability}

Human endocervical cells (End1/E6E7) were used to determine relative sensitivity to $\mathrm{REHb} \beta \mathrm{P}$. Human endocervical cells were seeded overnight in a 96-well plate at a density of $1 \times 10^{5}$ cells /well. After exposure to REHb $\beta \mathrm{P}(60.61 \mu \mathrm{M})$ for $24 \mathrm{~h}$, cells were evaluated microscopically for any change in the cell morphology. Light microscopy results revealed that cells treated with REHb $\beta \mathrm{P}$ showed smooth surface, firm anchorage to the substratum and no visibly evident loss in cell number and morphology. These results were further 
confirmed by cell ELISA, which indicate no significant loss in the cell viability of End1/E6E7 cells as against $>90 \%$ cell death in Triton X-100 treated cells (Figure 8).

\section{REHb $\beta P$ expressed by rabbit epididymal tissue and spermatozoa}

Secreted epididymal proteins are known to bind to spermatozoa with varying tenacities. To elucidate the nature of the binding of the REHb $\beta \mathrm{P}$ to the epididymal tissue and sperm plasma membrane, indirect immunofluorescent staining was performed. Confocal laser scanning microscopy results revealed that $\mathrm{REHb} \beta \mathrm{P}$ was detected on stereocilia in the lumen of cauda epididymal epithelium and on the sperm surface covering the acrosome region in freshly ejaculated sperm (Figure 9).

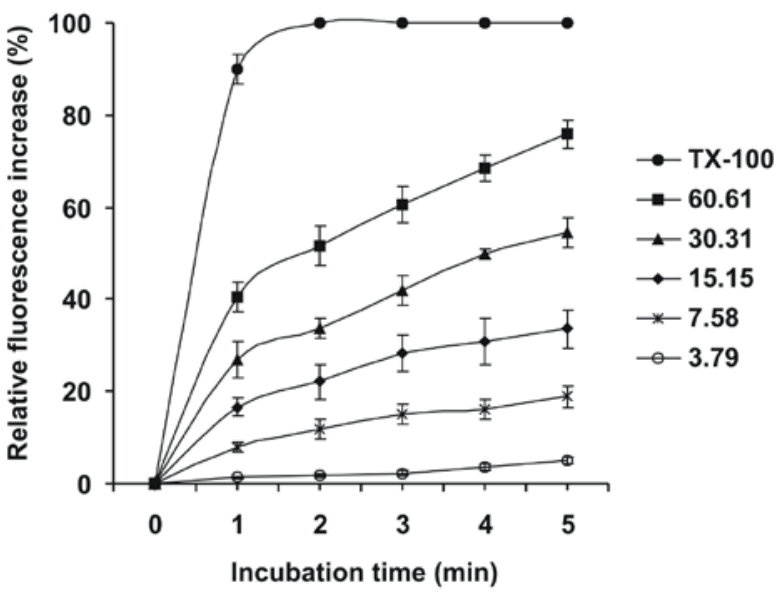

Figure 7: Dye leakage pattern induced by REHbßP in calcein enclosed liposomes. Liposomes mimicking microbial membranes (containing PC and PS) were incubated with indicated concentrations of REHbßP and intensity of calcein leakage at different time points was monitored. Maximum leakage was observed with $60.61 \mu \mathrm{M}$ and $30.31 \mu \mathrm{M}$ while considerably less leakage was observed with $50 \mu \mathrm{M}$ and $25 \mu \mathrm{M}$ when compared with leakage induced by $0.1 \%$ Triton $X-100$. Each value is the mean \pm S.D of six individual observations obtained from three separate experiments performed on different days.

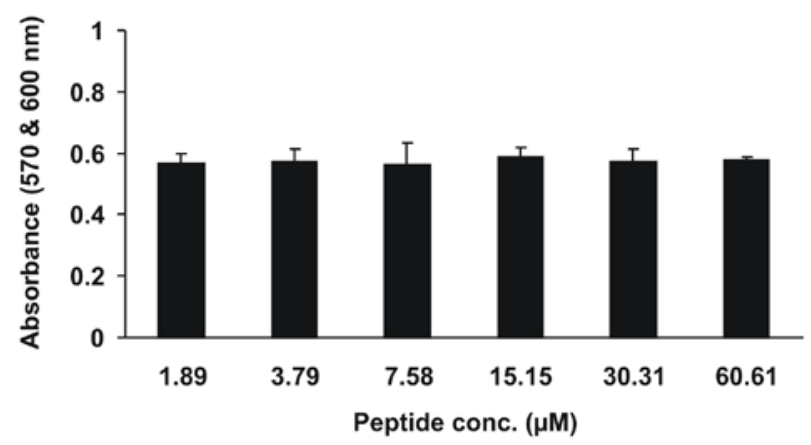

Figure 8: In vitro effect of REHbßP on the viability of human endocervical cells (End1/E6E7) evaluated by KineticBlue assay. The peptide non-toxic to End1/ E6E7 cells. Each value is a mean \pm S.D of six individual observations obtained from three different experiments performed on different days. Each value is the mean \pm S.D of six individual observations obtained from three separate experiments performed on different days.
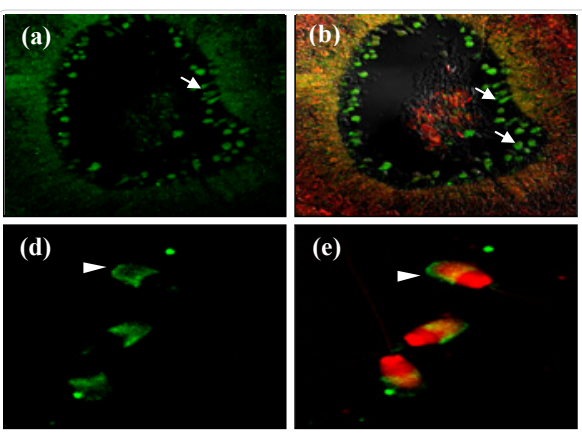

Figure 9: Images showing the expression of REHbßP in the cauda epididymis (Mag X 40) (a-c) and spermatozoa (d-f) (Mag X 100) (a,d= FITC; b,e= PI, FITC merge and $\mathrm{c}, \mathrm{f}=$ pre-immune controls). Stereocilia of epididymis and spermatozoa are positive for REHbßP. The protein localized on the acrosome of the sperm (PSCE= Pseudo-stratified columnar epithelium). The figures shown are the representative pictures from three independent experiments

\section{Discussion}

Sexually transmitted infections (STIs) remain a public health problem of major significance in most parts of the world. The reproductive tract invaded by microorganisms, and may contribute to infertility in humans and animals, if left untreated they predispose to secondary infections $[16,25]$. In addition to all these problems, the levels of resistance to antibacterial agents are increasing at an alarming rate as antibiotics are progressively demonstrating decreased efficacy. Gonorrhoeae and syphilis, once easily cured, have become resistant to many of the older traditional antibiotics [24]. Therefore it is an urgent need to identify molecules having antibacterial properties for the prevention of STIs.

In the present study we demonstrated that, EPECs of rabbit respond to CpG-ODN stimulation, and synthesize an array of AMPs. MALDITOF-MS results of the RP-HPLC pooled fractions (P1-P5) named as RESAMP, demonstrate that of the four proteins (hemoglobin- $\alpha$ and $\beta$ peptides, transthyretin and calreticulin that were reacted with HIV antigens (gp120. gp41, gp17 and p24), hemoglobin- $\beta$ (Hb- $\beta$ ). The 15 amino acid fragment of the rabbit $\mathrm{Hb}-\beta$, corresponding to the region of 110-124 (LVIVLSHHFGKEFTP) was further characterized as it showed the highest PBMS score of 99 as compared to other three proteins (Table 2 and supplemented figure 4). Using AMP Database and bioinformatics tools, we synthesized a 29 mer peptide, REHb $\beta \mathrm{P}$ (RLLGNVLVIVLSHHFGKEFTPQVQAAYQK), which demonstrated significant antibacterial activity against several infectious pathogens. The results indicated that the presence of $\mathrm{Hb}$ derived peptides in rabbit epididymis is surprising, since globin genes are normally expressed by erythroid cell lineages. However, few studies have indicated the expression $\mathrm{Hb}-\beta$ gene in cell lineages of non-erythroid origin (human fibroblasts, macrophages and HeLa cells) after stimulation with LPS [26]. Two elegant studies from Cornelia et al. [27] and Du et al. [28] revealed the entire hemoglobin molecule might not be a antibacterial, but the hemoglobin fragments released from RBCs can be microbicidal.

Epididymis of rat and human are rich source of AMPs [2,9]. However it remains to be investigated in the rabbits. AMPs from hemoglobin were first reported in 1999 [29]. At that time this property was dismissed as not being biologically relevant. Although $\mathrm{Hb}$ was first identified as oxygen transporter, recent studies have clearly demonstrated that peptides originated from $\mathrm{Hb}$ of humans and other species possess strong activity against Gram negative and Gram positive bacteria and participate in host defense against pathogens $[25,27,30]$. 
Citation: Reddy KVR, Deva S, Aranha C, Patgaonkar MS, Bhonde G (2011) Identification and Characterization of Molecules Having Anti-microbial Activities from Rabbit Epididymis Using Proteomic Approach. J Microbial Biochem Technol S2:002. doi:10.4172/1948-5948.S2-002

Recent studies have clearly indicated that $\mathrm{Hb}$ acts as a precursor for AMP production $[28,31]$ and $\mathrm{Hb}$ derived peptides recognize PAMPs like lipopolysaccharide (LPS) [26,32]. The proteolytically generated AMPs (hemocidins) identified in human uterine secretions, cervical mucous and menstrual blood were belong to $\mathrm{Hb}$ family [33]. Therefore, the present study strongly suggests that $\mathrm{Hb}$ derived peptide fragments may be conserved evolutionarily across a wide range of mammals, and REHb $\beta$ P could be one such fragment produced by EPECs during bacterial infection. Although speculative, we postulate that $\mathrm{Hb}$ derived peptide could be synthesized by EPECs and released into the lumen as fragments of cellular $\mathrm{Hb}$. In any case, the functional significance of such extra-erythrocytically expressed $\mathrm{Hb}$ derived proteins in rabbit epididymis has been unclear at present and warrant further studies.

Hydropathy plot of deduced amino acid sequence of REHb $\beta \mathrm{P}$ indicated that it could be a hydrophobic protein and hydrophobicity may be attributed to the probable association of REHb $\beta$ P with LPS in the bacterial cell membrane. Analysis of the REHb $\beta \mathrm{P}$ sequence using the Kyte Doolittle plot demonstrated a significant presence of hydrophobic amino acids concentrated in the N-terminal region of the protein (Supplemented figure $5 \mathrm{a} \& 5 \mathrm{~b}$ ). This clearly suggests that the amino acids of the REHb $\beta$ P are the part of $\alpha$-helix and might be able to span across a lipid bilayer membrane. The 29 amino acid peptide of the $\mathrm{Hb}-\beta$ subunit of rabbit, could be associated with antimicrobial activity and tended to form a-helical structures as reported for other AMPs [30]. Based on the theoretical analysis of $\beta$-chain of rabbit hemoglobin, the protein we isolated is in the highest hydrophobic region of the $\beta$ -chain of rabbit hemoglobin. This shows that the hydrophobicity of the protein is related to its anti-microbial activity. Higher hydrophobicity is required for binding to the LPS in the outer membrane of gram negative bacteria.

Indirect Immunofluorescence studies revealed that REHb $\beta \mathrm{P}$ was localized in the cytoplasm of epididymal epithelia demonstrated that REHb $\beta$ P perhaps related to secretory protein absorbed by spermatozoa, may play a vital role in sperm protection besides maturation during passage in the epididymis and post ejaculation in the vagina. However, it is not clear at present whether $\mathrm{REHb} \beta \mathrm{P}$ fragment present in a fully soluble form or absorbed and stored in luminal vesicles such as stereocilia and are then transferred by unknown mechanisms to the sperm plasma membrane. These studies are supported by various other studies which showed presence of various AMPs viz., sperm associated antigen (SPAG11) also known as epididymal protein 2 (EP2) in monkey, human epididymis 2 (HE2) and rat spag 11 are AMPs attached on the sperm surface $[2,8]$.These evidences also suggest that epididymal proteins are secreted into the luminal fluid in a soluble form and bind to specific regions of the sperm surface. Given the antimicrobial function of REHb $\beta$, it may have a putative role in protecting epididymal sperm from bacterial infections. However, several studies are required to answer certain queries. First, the mechanism of secretion of REHb $\beta P$ by EPECs is still contentious. Second, the specificity and tenacity with which REHb $\beta$ P bind to the sperm plasma membrane, and ultimately their structure within it, remain problematic. Third, what evolutionary forces drove the selection and maintenance of so many AMPs in this important organ of sperm maturation? We believe that one possibility could be that each AMP evolved to control a different species of microorganisms. The environment in each organ may be conducive to growth of different microbial species. We speculate the infection would be much worse if $\mathrm{Hb}$ had no antimicrobial activity. Meanwhile, the present findings suggest that similar to human and rabbit vaginal fluids $[16,25,31]$, rabbit epididymal fluid may also serve as an AMP bank which participate in defending the host against infections.

To gain further insight into the antibacterial mechanism of $\mathrm{REHb} \beta \mathrm{P}$, we next investigated its ability to interact with bacterial cell membrane. The results reveal that anti-bacterial activity of REHb $\beta \mathrm{P}$ could be attributed to its net positive charge and hydrophobic ratio. To evaluate the mode of interaction of $\mathrm{REHb} \beta \mathrm{P}$ with bacterial membranes, liposomes were prepared using Phosphatidylcholine (PC) and Phosphatidylserine (PS), which serves as a model for the negatively charged cytoplasmic membranes of bacteria. The fact that REHb $\beta \mathrm{P}$ induced maximum calcein leakage from liposomes, at a concentration of $60.61 \mu \mathrm{m}$, is in concurrence with the MIC results obtained with a similar dose. These studies strongly suggest that REHb $\beta$ P could be one among the key antimicrobial factors produced in the epididymis when the EPECs sense any microbial threat.

Our study marks for the first time in the evaluation of antimicrobial profiles in the rabbit epididymis, which lead to the identification of cationic AMP of $\mathrm{Hb}$ origin, which we demonstrated to be one of the components responsible for the microbicidal activity. From the present findings, it may be envisaged that rabbit epididymal fluid is an antiinfectious medium and REHb $\beta \mathrm{P}$ may be involved protection against potentially harmful microbes. This peptide appears to be an attractive candidate for therapeutic agents due to its specific interactions with pathogens and low toxicity to erythrocytes and human endocervical cells. Establishing the role of REHb $\beta \mathrm{P}$ in epididymal innate immunity may further unravel the intricacies in epididymal defense in this species, and is the current focus of the research in our laboratory. Taken together, this discovery may have significant impact not only in the basic antimicrobial biology of hemoglobin, but also in understanding the pathogenesis associated with microbial infection in epididymis.

\section{Acknowledgements}

The authors are grateful to the Director for giving encouragement in carrying out this study. This study was partially supported by grants from Department of Biotechnology (DBT, New Delhi) and Indian Council of Medical Research (ICMR New Delhi) (NIRRH/MS/28 / 2010). We thank Mrs. Reshma Goankar for assistance in Confocal Imaging. We thank DBT and Lady Tata Trust for providing junior and senior research Fellowships to SD and MP respectively. The authors are thankful to Mr. Mangesh Malvankar for secretarial assistant.

\section{References}

1. Reddy KVR, Yedery RD, Aranha CC (2004) Antimicrobial peptide: Premises and promises. Int J Antimicrobial Peptides 24: 536-547.

2. Hall SH, Hamil KG, French FS (2002) Host defense proteins of the male reproductive tract. J Androl 23: 585-597.

3. Dejucq N, Jegou B (2001) Viruses in the mammalian male genital tract and their effects on the reproductive system. Microbiol Mol Biol Rev 65: 208-231.

4. Liao M, Ruddock PS, Rizvi AS, Hall SH, French FS, et al. (2005) Cationic peptide of the male reproductive tract, $\mathrm{HE} 2 \alpha$, displays antimicrobial activity against Neisseria gonorrhoeae, Staphylococcus aureus and Enterococcus faecalis. Journal of Antimicrobial Chemother 56: 957-961.

5. Purvis K, Christiansen E (1993) Infection in the male reproductive tract. Impact diagnosis and treatment in relation to male infertility. Int $\mathrm{J}$ Androl 16: 1-13.

6. Chan HC, Zhang YL (2005) Epididymial defensins and sperm maturation Andrologia 37: 200-201.

7. Gatti JL, Metayer S, Belghazi M, Dacheux F, Dacheux JL (2005) Identification, proteomic profiling and origin of ram epididymal fluid exosome-like vesicles. Biol Reprod 72: 1452-1465.

8. Yenugu S, Richardson RT, Sivashanmugam P, Wang Z, O'Rand MG, et al (2004) Antimicrobial activity of human EPPIN, an androgen-regulated, spermbound protein with a whey acidic protein motif. Biol Reprod 71: 1484-1490. 
Citation: Reddy KVR, Deva S, Aranha C, Patgaonkar MS, Bhonde G (2011) Identification and Characterization of Molecules Having Anti-microbial Activities from Rabbit Epididymis Using Proteomic Approach. J Microbial Biochem Technol S2:002. doi:10.4172/1948-5948.S2-002

Page 11 of 11

9. Li P, Chan HC, He B, So SC, Chung YW, et al. (2001) An antimicrobial peptide gene found in the male reproductive system of rats. Science 291: 1783-1785.

10. Horsten HHV, Der P, Kirchhoff C (2002) Novel antimicrobial peptide of human epididymal duct origin. Biol Reprod 67: 804-813.

11. Yamaguchi Y, Nagase T, Makita R, Fukuhara S, Tomita T, et al. (2010) Identification of Multiple Novel Epididymis-Specific $\beta$-Defensin Isoforms in Humans and Mice. J Immunol 169: 2516-2523.

12. Hammami HS, Doussau M, Bernard J, Rogier E, Duquenne C, et al. (2001) Cloning and sequencing of SOB3, a human gene coding for a sperm protein homologous to an antimicrobial protein and potentially involved in zona pellucida binding. Mol Hum Reprod 7: 625-632.

13. Malm J, Sorensen O, Persson T, Frohm-Nilsson M, Johansson B (2000) The human cationic antimicrobial protein (hCAP18) is expressed in the epithelium of human epididymis, is present in seminal plasma at high concentrations and is attached to spermatozoa. Infect Immun 68: 4297-4302.

14. Liu Q, Hamil KG, Sivashanmugam P, Grossman G, Soundararajan R, et al. (2001) Primate epididymis-specific proteins: characterization of ESC42, a novel protein containing trefoil-like motif in monkey and human. Endocrinology 142: 4529-4539.

15. Hu J, Xu M, Hang B, Wang L, Wang Q, et al. (2010) Isolation and characateriation of an antimicrobial peptide from bovine hemoglobin $\alpha$-subunit. World J Microbiol Biotechnol 27: 767-771.

16. Mandar PM, Aranha CC, Bhonde G, Reddy KVR (2010) Identification and characterization of anti-microbial peptides from rabbit vaginal fluid. Vet Immuno Immunopathol 139: 176-186.

17. Bradford MM (1976) A rapid and sensitive method for the quantitation of microgram quantities of protein utilizing the principle of protein-dye binding. Anal Biochem 72: 248-254.

18. Yedery RD, Reddy KVR (2009) Purification and characterization of antibacteria components from the granular hemocytes of Indian mud crab, Scylla serrata. Acta Biochemica Polonica 56: 71-82.

19. Hall RA (2004) Studying protein-protein interactions via blot overlay or far western blot. In protein-protein interactions, methods and applications, methods in molecular biology Fu H (Ed) Humana Press, Totowa NJ, pp167-174

20. Shevchenko A, Wilm M, Vorm O, Mann M (1996) Mass spectrometric sequencing of proteins silver-stained polyacrylamide gels. Anal Chem 68: 850858.
21. Liu LP, Deber CM (1997) Anionic phospholipids modulate peptide insertion into membranes. Biochemistry 36: 5476-5482.

22. Yedery RD, Reddy KVR (2009) Identification, cloning, characterization and recombinant expression of an anti-lipopolysaccharide factor from the hemocytes of Indian mud crab, Scylla serrata. Fish Shellfish Immuno 27: 275284.

23. CohenYW, Shai Y (2007) Demonstrating the C-terminal boundary of the HIV 1 fusion conformation in a dynamic ongoing fusion process and implication for fusion inhibition. FASEB Journal 21: 3677-3684.

24. Reddy KVR, Aranha CC, Gupta SM, Yedery RD (2004) Evaluation of antimicrobial peptide, Nisin as a safe vaginal contraceptive agent in rabbits: in vitro and in vivo studies. Reproduction 128: 126-137.

25. Valore EV, Park CH, Quayle AJ, Wiles KR, McGray Jr PB, et al. (1998) Human beta-defensin-1: an antimicrobial peptide of urogenital tissues. J Clin Invest 101: 1633-1642.

26. Kaca W, Roth RI, Levin J (1994) Hemoglobin: a newly recognized lipopolysaccharide (LPS) binding protein which enhances LPS biological activity. J Biol Chem 269: 25078-25084.

27. Cornelia L, Susann B, Cornelia H (2003) Human hemoglobin-derived peptides exhibit antimicrobial activity. J Chromatogr 791: 345-356.

28. Du R, Ho B, Ding JL (2010) Rapid reprogramming of haemoglobin structurefunction exposes multiple dual-antimicrobial potencies. The EMBO J 29: 632642.

29. Fogaca AC, Jr da Silva PI, Miranda MT, Bianch AG, Miranda A, et al. (1999) Antimicrobial activity of a bovine hemoglobin fragment in the tick Boophilus microplus. J Biol Chem 274: 25330-25334

30. Pawel M, Kinga W, Jerzy S (2000) Antimicrobial peptides derived from hemecontaining proteins: hemocidins. Antonie Van Leeuwenhoek 77: 197-207.

31. Mak $P$ (2008) Hemocidins is a functional and structural context of human antimicrobial peptides. Front Bioscien 13: 6859-6871.

32. Parish CA, Jiang H, Tokiwa Y, Berova N, Nakanishi K, et al. (2001) Broadspectrum antimicrobial activity of hemoglobin. Bioorg Med Chem 9: 377-382.

33. Deng L, Pan X, Wang Y, Wang L, Zhou XE, et al. (2009) Hemoglobin and its derived peptides may play a role in the antibacterial mechanism of the vagina. Human Reprod 24: 211-218. 